\title{
NILAI SUN PROTECTION FACTOR EKSTRAK METANOL DAUN RAMBUTAN (Nephelium lappaceum) DENGAN SPEKTROFOTOMETRI
}

\author{
Mirtaati Na'ima ${ }^{\left.1^{*}\right)}$ \\ ${ }^{1 *}$ E-mail: mirtaati@ walisongo.ac.id
}

\author{
${ }^{1)}$ Program Studi Pendidikan Biologi, Fakultas Sains dan Teknologi, Universitas \\ Islam Negeri Walisongo Semarang.
}

\begin{abstract}
Research on natural sunscreen continues to be developed to obtain safer sunscreen agents. Sunscreen is needed to protect skin from ultraviolet $(U V)$ rays danger. Ultraviolet rays can be beneficial, but become harmful when exceeded. The ability of a material to protect against harmful $U V$ rays is usually expressed in terms of the sun protection factor (SPF). This study was conducted to determine the SPF value of rambutan (Nephelium lappaceum) leaf methanol extract. This research can later be used to add insight into the potential of rambutan leaves to be used as a natural sunscreen agent. The extraction process uses methanol to macerate the dried leaves. The SPF value was measured in vitro using the spectrophotometric method, then the absorbance value was obtained using the Mansur equation. The extraction process produces a greenish black paste extract with a distinctive leaf aroma. The methanol extract of rambutan leaves with concentrations of 100, 200, 300, 400, 500, and 1000 ppm has the ability to protect against UV rays, expressed in SPF values of 5,710, respectively; 10,398; 16,320; 20,920; 26,152; and 37,983. Different results from the same plant can occur due to the using of different parts of the plant as a simplisias as well as different types of organic solvents used for the extraction process. In this study, methanol extract of rambutan leaves at concentrations of 100 and $200 \mathrm{ppm}$ had minimal protective ability, extract concentration of 300-500 ppm had moderate protection ability, while extract concentration of 1000 ppm had high protective ability.
\end{abstract}

Keywords: sunscreen, bioactive compounds, SPF in vitro, Mansur's equation, UV rays

\section{ABSTRAK}

Penelitian pencarian agen tabir surya alami terus dikembangkan untuk mendapatkan agen tabir surya yang lebih aman. Tabir surya diperlukan untuk melindungi kulit dari bahaya sinar ultraviolet (UV). Sinar UV dapat bermanfaat bagi tubuh, namun menjadi berbahaya jika berlebih. Kemampuan suatu bahan dalam melindungi dari bahaya sinar UV biasa dinyatakan dalam sun protection factor (SPF). Penelitian ini bertujuan untuk mengetahui nilai SPF ekstrak metanol daun rambutan (Nephelium lappaceum). Penelitian ini nantinya dapat digunakan untuk menambah wawasan mengenai potensi daun rambutan untuk digunakan sebagai agen tabir surya alami. Proses ekstraksi menggunakan metode maserasi dengan pelarut metanol. Pengukuran nilai SPF dilakukan secara in vitro menggunakan metode spektrofotometri kemudian nilai absorbansi yang diperoleh dihitung menggunakan persamaan Mansur. Proses ekstraksi menghasilkan ekstrak pasta hitam kehijauan beraroma khas daun. Ekstrak metanol daun rambutan dengan konsentrasi 100, 200, 300, 400, 500, dan 1000 ppm memiliki kemampuan proteksi terhadap sinar UV, dinyatakan dalam nilai SPF berturut-turut sebesar 5,710;10,398; 16,320;20,920;26,152; dan 
37,983. Hasil yang berbeda dari tanaman yang sama dapat terjadi dikarenakan pengambilan bagian tubuh tanaman yang berbeda untuk diekstrak serta penggunaan jenis pelarut organik yang berbeda untuk proses ekstraksinya. Dalam penelitian ini, ekstrak metanol daun rambutan pada konsentrasi 100 dan 200 ppm memiliki kemampuan proteksi minimal, konsentrasi ekstrak 300500 ppm memiliki kemampuan proteksi sedang, sedangkan konsentrasi ekstrak 1000 ppm memiliki kemampuan proteksi tinggi.

Kata Kunci: tabir surya, senyawa bioaktif, SPF in vitro, persamaan Mansur, sinar UV

\section{PENDAHULUAN}

Penggunaan tabir surya merupakan hal yang sangat penting untuk melindungi kulit manusia dari bahaya sinar ultraviolet (UV), terutama bagi yang tinggal di negara tropis seperti Indonesia. Sinar UV dapat ditemukan di dalam cahaya matahari. Sinar UV memiliki manfaat bagi manusia. Namun, jika jumlahnya berlebih, sinar UV dapat menimbulkan kerusakan. Wilayah beriklim tropis menerima paparan sinar matahari lebih banyak dibandingkan wilayah dengan iklim yang lain. Intensitas sinar UV yang diterima wilayah tropis juga lebih tinggi dibandingkan wilayah lain (Isfardiyana \& Safitri, 2014).

Sinar UV merupakan suatu gelombang elektromagnet dalam cahaya matahari yang memiliki spektrum berbeda dengan cahaya tampak. Panjang gelombang sinar UV lebih tinggi dari cahaya tampak. Cahaya tampak berada pada kisaran panjang gelombang 400-700 nm (Narla et al., 2020). Sinar UV berada pada kisaran panjang gelombang di bawahnya, yaitu 10-400 $\mathrm{nm}$. Sinar UV dapat digolongkan menjadi tiga, yaitu UV A, UV B, dan UV C. Sinar UV A memiliki kisaran panjang gelombang 400-320 nm, sinar UV B 320-290 nm, sedangkan sinar UV C 290-10 nm (Isfardiyana \& Safitri, 2014). Sinar UV C adalah yang paling berbahaya, namun sinar ini tidak sampai ke bumi karena tertahan oleh atmosfer. Sinar UV A tidak berbahaya dan banyak dimanfaatkan untuk pewarnaan kulit. Sinar UV B cukup berbahaya karena dapat merusak kulit dan mata jika berlebih (Faridah, 2018).

Sinar UV telah lama diketahui sebagai agen mutagenik yang mampu menyebabkan kerusakan struktur dan fungsi makromolekul tubuh seperti DNA, protein dan lipid, hingga menyebabkan munculnya kanker (Bernard et al., 2019). Penggunaan pakaian tertutup, berlindung di bawah bayangan benda yang tinggi, dan menggunakan tabir surya dengan nilai sun protection factor (SPF) minimal 15 disarankan oleh National Health Interview Survey (NHIS) untuk melindungi kulit dari bahaya sinar UV (Watson et al., 2016).

Tabir surya adalah bahan yang dapat melindungi kulit dari bahaya yang ditimbulkan oleh sinar UV (Mansuri et al., 2021). Tabir surya dapat berasal dari bahan sintetis maupun alami. Tabir surya dari bahan sintetis misalnya titanium dioksida $\left(\mathrm{TiO}_{2}\right)(\mathrm{Ollengo} \& \mathrm{Nthiga}, 2021)$, oksibenzon, 
asam benzoate amino, padimat, dan lain sebagainya (Mansuri et al., 2021). Tabir surya dari bahan alami dapat berasal dari senyawa golongan likopen, fenol, asam sinamat, asam miristat (Darmawan et al., 2022), dan lignin (Piccinino et al., 2021).

Kemampuan suatu bahan sebagai tabir surya dapat diukur sebagai nilai Sun Protection Factor (SPF). Sun Protection Factor adalah perbandingan antara energi radiasi UV yang dibutuhkan untuk menimbulkan eritrema minimal pada kulit yang terlindung oleh suatu tabir surya dengan energi radiasi UV yang dibutuhkan untuk menimbulkan eritrema minimal pada kulit tanpa tabir surya (Mansuri et al., 2021).

Tabir surya alami dapat dengan mudah ditemukan dari bahan alam di Indonesia. Bahan alam ini seperti kulit buah pisang ambon (Himawan et al., 2018), beras hitam (Farhamzah et al., 2022), buah pepaya (Rakhmatullah et al., 2020), tongkol jagung (Lumempouw et al., 2012), buah jamblang (Adhayanti et al., 2019), serta kayu manis dan kulit delima (Rusita \& A.S, 2017). Di samping itu, tabir surya alami juga dapat ditemukan di tanaman lain, seperti rambutan.

Rambutan (Nephelium lappaceum) adalah tanaman buah yang banyak dibudidayakan di Indonesia. Selain untuk dimakan buahnya, tanaman ini memiliki banyak manfaat di bidang kesehatan sebagai antioksidan, antidiabetik, antimikrobia, antivirus, dan antikanker (Perumal et al., 2021). Penelitian Putri et al. (2019) menunjukkan bahwa ekstrak kulit buah rambutan memiliki potensi untuk digunakan sebagai tabir surya, dibuktikan dengan uji SPF in vitro yang menunjukkan nilai 9,991. Hasil penelitian tersebut mendorong dilakukannya penelitian untuk menggali potensi bagian lain dari tanaman rambutan untuk digunakan sebagai tabir surya.

Daun rambutan jumlahnya melimpah dan ketersediaannya tidak bergantung pada musim tertentu. Penelitian mengenai penelusuran potensi tabir surya dari daun sudah banyak dilakukan sebelumnya. Sebagai contoh, penelitian pada daun salam (Utami et al., 2021), daun ketepeng cina dan binahong (Lestari \& Prajuwita, 2021), daun kecombrang (Pramiastuti, 2019), daun buas-buas (Puspita \& Puspasari, 2021), daun jambu air (Salsabila et al., 2021), daun kelor (Sagala \& Juniasti, 2021), serta daun mangga gedong (Lisnawati et al., 2019). Penelitian ini bertujuan untuk megetahui potensi daun rambutan sebagai tabir surya. Manfaat yang didapatkan dari penelitian ini adalah masyarakat dapat memperoleh informasi mengenai potensi daun rambutan sebagai agen tabir surya alami.

\section{METODE PENELITIAN}

Penelitian ini merupakan penelitian eksperimental laboratorik, dilakukan di Laboratorium Biologi Fakultas Sains dan Teknologi UIN Walisongo Semarang. Sampel berupa daun segar dari 
tanaman rambutan kultivar Aceh diambil dari Kelurahan Bringin, Kecamatan Ngaliyan, Semarang.

Metode ekstraksi memodifikasi metode De Silva et al. (2019). Daun rambutan yang diperoleh dicuci untuk menghilangkan debu yang menempel pada permukaan daun. Daun selanjutnya dikering anginkan hingga daun tidak lagi basah oleh air pencuci. Daun rambutan kemudian dibungkus dengan kertas dan dikeringkan dalam oven dengan suhu tidak lebih dari $45^{\circ} \mathrm{C}$ selama 4 hari. Daun yang sudah kering dihaluskan menggunakan blender dry mill (Philips HR2815). Serbuk daun dimaserasi menggunakan metanol (Merck) dengan perbandingan antara serbuk daun dan pelarut sebesar 1:5 (w/v). Maserasi ini dilakukan selama 3 hari dengan pengadukan sehari sekali pada kondisi tertutup cahaya. Penyaringan dilakukan pada hari ketiga proses maserasi. Remaserasi dilakukan secara berulang dan dihentikan ketika maserat yang diperoleh tampak bening. Maserat dipekatkan dengan rotary evaporator dan diuapkan hingga diperoleh ekstrak.

Ekstrak diencerkan kembali menggunakan pelarut metanol untuk membuat larutan stok ekstrak dengan konsentrasi 1000 ppm. Dalam hal ini, 10 mg ekstrak dilarutkan dengan metanol hingga mencapai volume $10 \mathrm{~mL}$. Pengenceran dilakukan untuk membuat larutan ekstrak dengan konsentrasi 100, 200, 300, 400, dan 500 ppm dengan mengambil stok masing-masing sebanyak 1, 2, 3, 4, dan $5 \mathrm{~mL}$. Stok yang diambil tersebut selanjutnya dilarutkan hingga masing-masing volumenya mencapai $10 \mathrm{~mL}$. Kelima larutan ekstrak dengan konsentrasi yang bervariasi ini kemudian diperiksa absorbansinya menggunakan spektrofotometer (Thermo-Scientific) pada panjang gelombang 290-320 nm dengan interval $5 \mathrm{~nm}$ dan metanol sebagai blankonya. Penggunaan variasi konsentrasi larutan ekstrak sebesar 100, 200, 300, 400, dan 500 ppm untuk pemeriksaan nilai SPF secara in vitro ini mengikuti metode Bahar et al. (2021). Selain variasi konsentrasi tersebut, pada penelitian ini juga dilakukan pemeriksaan nilai SPF pada larutan stok ekstrak (konsentrasi 1000 ppm). Pengukuran dilakukan sebanyak tiga kali pengulangan (triplo). Nilai absorbansi yang diperoleh kemudian dimasukkan dalam rumus perhitungan Mansur (Lestari \& Prajuwita, 2021). Adapun rumus perhitungan Mansur dapat dilihat pada Gambar 1.

$$
S P F=C F \times \sum_{290}^{320} E E(\lambda) \times I(\lambda) \times \text { absorbansi }(\lambda)
$$

Gambar 1. Rumus perhitungan SPF in vitro Mansur. $\mathrm{CF}=$ faktor koreksi (10); $\mathrm{EE}=$ spektrum efek eritema; I = spektrum intensitas sinar UV dari matahari (Utami et al., 2021)

Sebagaimana tampak pada Gambar 1, rumus Mansur memerlukan nilai spektrum efek eritema (EE) yang dikalikan dengan intensitas sinar UV (I). Nilai ini dapat dilihat pada Tabel 1. Suatu bahan dikategorikan memiliki kemampuan proteksi tinggi jika nilai SPF yang diperoleh 
adalah lebih dari 30, sedang jika nilai SPF yang diperoleh antara 12-30, minimal jika nilai SPF antara 2-11, dan dinyatakan bukan tabir surya jika nilai SPF yang diperoleh lebih rendah dari 2 (Cahyani \& Erwiyani, 2021).

Tabel 1. Nilai spektrum efek eritema (EE) kali intensitas sinar UV (I)

\begin{tabular}{cc}
\hline Panjang Gelombang (nm) & EE x I \\
\hline 290 & 0,0150 \\
295 & 0,0817 \\
300 & 0,2874 \\
305 & 0,3278 \\
310 & 0,1864 \\
315 & 0,0839 \\
320 & 0,0180 \\
\hline & (Utami et al., 2021)
\end{tabular}

\section{HASIL DAN PEMBAHASAN}

Tanaman yang digunakan dalam penelitian ini adalah tanaman rambutan kultivar Aceh. Morfologi daun dan buah rambutan dapat dilihat pada Gambar 2.

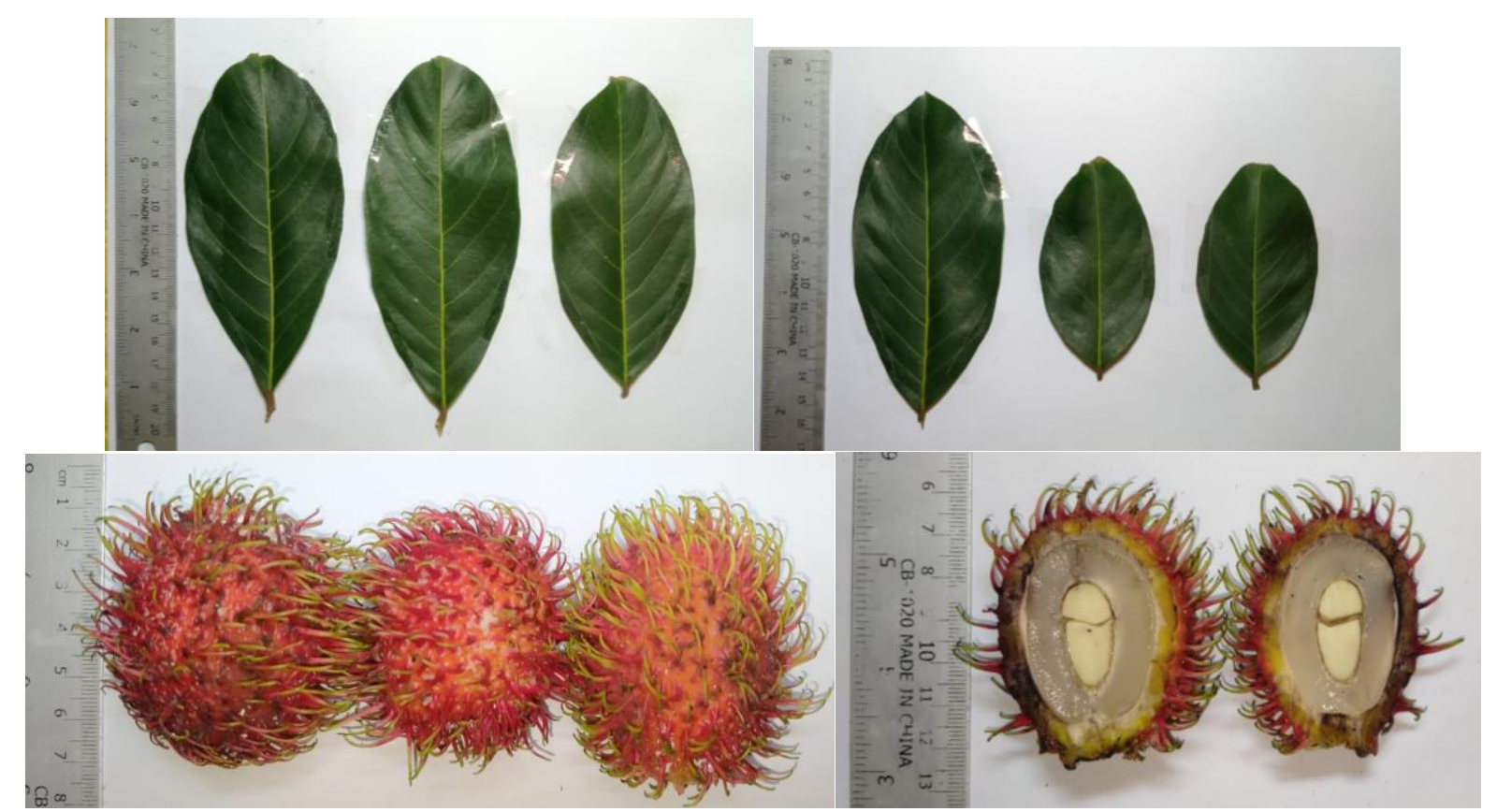

Gambar 2. Morfologi daun (atas) dan buah (bawah) rambutan

Dari Gambar 2, dapat dilihat morfologi daun rambutan kultivar Aceh yang digunakan sebagai bahan baku dalam pembuatan ekstrak memiliki bentuk bervariasi antara eliptical-oblong dan obovate. Ujung daun bervariasi antara acute dan acuminate. Pangkal daun berbentuk acute. Setiap tangkai tanaman ini terdapat daun dengan jumlah antara 4 hingga 6 helai. Warna daun hijau 
tua. Helaian daunnya tebal, menyerupai perkamen. Permukaan daunnya halus dan tepi daun rata. Hal ini serupa dengan hasil penelitian Windarsih (2022), yang mendapatkan morfologi daun rambutan kultivar Aceh serupa. Buah rambutan berbentuk ovoid dengan panjang 4,9 $\mathrm{cm}$ dan lebar 4,0 cm. Ketebalan aril 7,4 mm dan ketebalan kulit buah 5,3 mm.

Sebanyak 8,97 gram serbuk daun rambutan dimaserasi dengan metanol. Maserat yang diperoleh kemudian dipekatkan hingga didapatkan ekstrak. Ekstrak yang didapat sebanyak 1,04 gram dengan spesifikasi seperti tertera dalam Tabel 2. Ekstrak ini nantinya digunakan dalam pengujian nilai SPF menggunakan metode spektrofotometri.

Tabel 2. Hasil uji organoleptik ekstrak metanol daun rambutan

\begin{tabular}{cc}
\hline Aspek & Karakter ekstrak \\
\hline Bentuk & Pasta \\
Warna & Hitam \\
Aroma & Aroma daun \\
Rendemen & $11,59 \% \mathrm{w} / \mathrm{w}$ \\
\hline
\end{tabular}

Tabel 2 menunjukkan bahwa ekstrak metanol daun rambutan yang telah dipekatkan memiliki konsistensi berupa pasta. Warna ekstrak adalah hitam dan beraroma khas seperti aroma daun. Gambaran ekstrak hasil maserasi daun rambutan dapat dilihat pada Gambar 3.

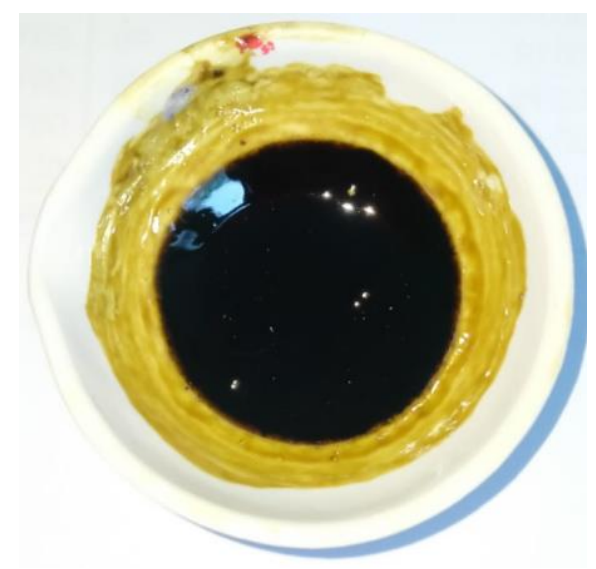

Gambar 3. Ekstrak metanol daun rambutan

Gambar 3 memperlihatkan gambar ekstrak sesuai dengan yang tertulis pada Tabel 2, yaitu ekstrak berupa pasta berwarna hitam. Sebanyak $10 \mathrm{mg}$ ekstrak dilarutkan kembali dengan metanol hingga $10 \mathrm{~mL}$ untuk mendapatkan konsentrasi 1000 ppm. Larutan ekstrak ini selanjutnya digunakan sebagai stok dalam pembuatan larutan ekstrak dengan konsentrasi 100, 200, 300, 400, dan 500 ppm. Larutan ekstrak dengan berbagai konsentrasi ini selanjutnya diperiksa dengan spektrofotometer untuk mencari nilai SPF. Absorbansi yang didapatkan dari hasil pemeriksaan ini dapat dilihat pada Gambar 4. 


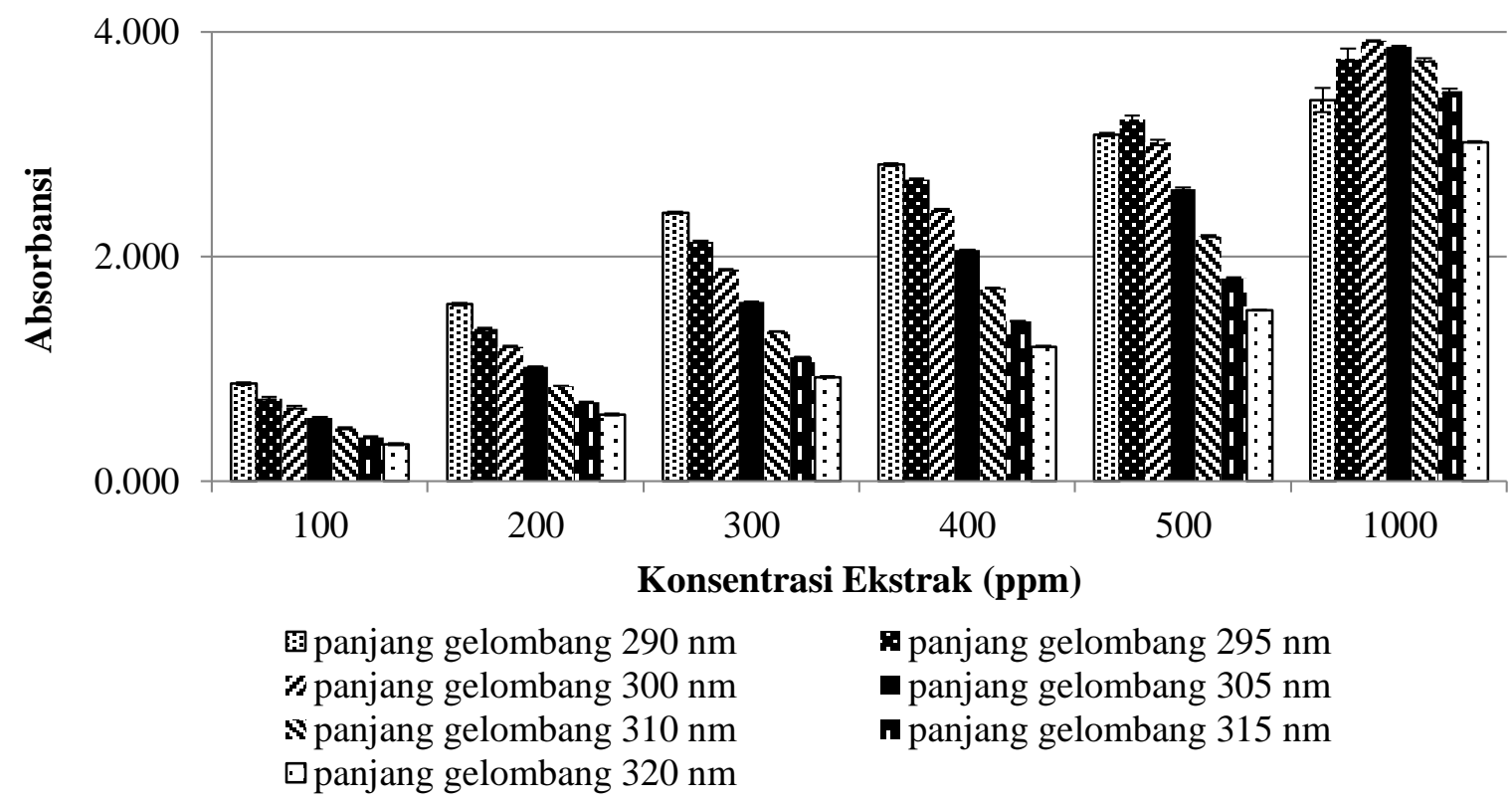

Gambar 4. Grafik nilai absorbansi ekstrak metanol daun rambutan pada konsentrasi 100, 200, 300, 400, 500, dan 1000 ppm.

Gambar 4 memperlihatkan absorbansi keenam konsentrasi larutan ekstrak pada panjang gelombang 290 hingga $320 \mathrm{~nm}$. Absorbansi meningkat seiring dengan kenaikan konsentrasi ekstrak. Selanjutnya absorbansi ini dimasukkan ke dalam rumus Mansur sehingga memperoleh nilai SPF seperti tertera pada Gambar 5.

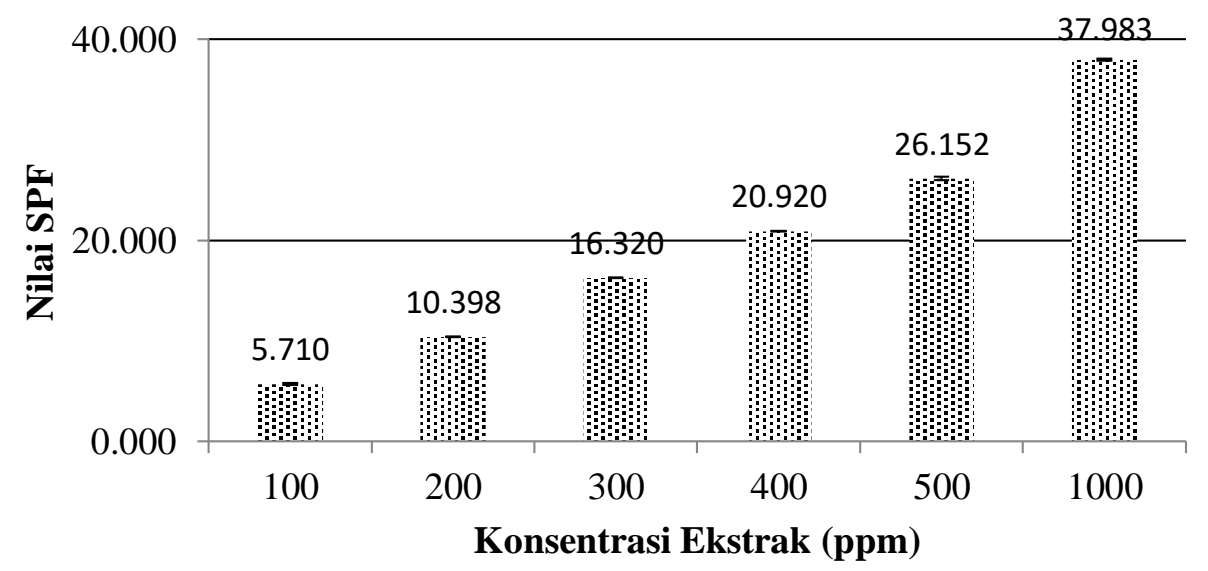

Gambar 5. Hasil perhitungan SPF dengan rumus Mansur dari nilai absorbansi yang diperoleh.

Gambar 5 menunjukkan bahwa ekstrak metanol daun rambutan dengan konsentrasi 100 dan 200 ppm menunjukkan proteksi minimal, konsentrasi 300 hingga 500 ppm menunjukkan proteksi 
sedang, dan konsentrasi 1000 ppm menunjukkan proteksi tinggi terhadap sinar UV. Penelitian sebelumnya oleh Putri et al. (2019) yang melakukan pemeriksaan nilai SPF in vitro dengan metode yang sama terhadap ekstrak etanol beberapa kulit buah menunjukkan bahwa nilai SPF ekstrak etanol kulit buah rambutan pada konsentrasi 100 ppm memiliki nilai SPF yang lebih tinggi daripada nilai SPF ekstrak metanol daun rambutan pada konsentrasi yang sama. Nilai tersebut adalah sebesar 9,991. Meskipun lebih tinggi, namun ekstrak etanol kulit buah rambutan juga memiliki tingkat proteksi yang sama dengan ekstrak metanol daun rambutan, yaitu proteksi minimal (Cahyani \& Erwiyani, 2021). Perbedaan nilai SPF yang terjadi ini mungkin dikarenakan oleh perbedaan jenis pelarut yang digunakan untuk ekstraksi. Ekstraksi menggunakan pelarut yang berbeda dapat menghasilkan ekstrak dengan kandungan senyawa bioaktif yang berbeda. Penelitian pada daun kedondong menunjukkan bahwa ekstrak yang diperoleh dari hasil maserasi menggunakan 3 pelarut yang berbeda, yaitu metanol, etanol, dan air, menunjukkan aktivitas antioksidan yang berbeda meskipun uji fitokimia kualitatif menunjukkan hasil yang sama (Rosyidah, 2021). Ketiga ekstrak tersebut mengandung flavonoid, tanin, dan triterpenoid, namun nilai $\mathrm{EC}_{50}$ ekstrak air, etanol, dan metanol berturut-turut adalah 7.044,2 ppm, 2659 ppm, dan 157,8 ppm.

Perbedaan hasil pengukuran nilai SPF ekstrak metanol daun rambutan dengan ekstrak etanol kulit buah rambutan dapat pula disebabkan oleh perbedaan bagian tubuh tanaman yang diekstrak. Penelitian lain menunjukkan bahwa pengukuran nilai SPF pada daun dan kulit batang Dillenia serrata memberikan hasil yang berbeda (Sinala et al., 2020). Konsentrasi ekstrak sebesar 100 ppm memberikan nilai SPF 4,612 untuk ekstrak kulit batang dan nilai SPF 1,554 untuk ekstrak daun. Ekstrak kulit batang dan ekstrak daun ini dihasilkan dari proses maserasi menggunakan pelarut etanol.

\section{KESIMPULAN}

Berdasarkan penelitian yang telah dilakukan, dapat diambil sebuah simpulan, yaitu nilai SPF ekstrak metanol daun rambutan pada konsentrasi 100, 200, 300, 400, 500, dan 1000 ppm berturutturut adalah 5,710;10,398; 16,320;20,920; 26,152; dan 37,983. Dengan demikian, ekstrak dengan konsentrasi 100 dan 200 dinyatakan memiliki kemampan proteksi minimal, ekstrak dengan konsentrasi 300 hingga 500 memiliki kemampuan proteksi sedang, serta ekstrak dengan konsentrasi 1000 ppm memiliki kemampuan proteksi tinggi. Penelitian lebih lanjut perlu dilakukan untuk mengetahui ada atau tidaknya perbedaan nilai SPF ekstrak daun rambutan yang diperoleh dengan menggunakan pelarut yang berbeda. 


\section{DAFTAR PUSTAKA}

Adhayanti, I., Nurisyah, \& Abdullah, T. (2019). AKTIFITAS UV PROTEKTIF EKSTRAK BUAH JAMBLANG UV. Media Farmasi, XV(1), 1-5.

Bahar, Y., K, F. S., \& Lestari, U. (2021). Penentuan Nilai Sun Protection Factor ( SPF ) Ekstrak Etanol Daun Jeruju ( Acanthus Ilicifolius L .) secara In vitro. Indonesian Journal of Pharma Science, 3(2), 91-96.

Bernard, J. J., Gallo, R. L., \& Krutmann, J. (2019). Photoimmunology: how ultraviolet radiation affects the immune system. Nature Reviews Immunology, 19(11), 688-701. https://doi.org/10.1038/s41577-019-0185-9

Cahyani, A. S., \& Erwiyani, A. R. (2021). Formulasi dan Uji Sun Protection Factor ( SPF ) Sediaan Krim Ekstrak Etanol 70 \% Daging Buah Labu Kuning ( Curcubita Maxima Durch ) Secara In vitro. Jurnal Farmasi (Journal of Pharmacy), 2(1), 1-11. https://doi.org/10.37013/jf.v2i1.149

Darmawan, M. A., Ramadhani, N. H., Hubeis, N. A., Ramadhan, M. Y. A., Sahlan, M., Abd-Aziz, S., \& Gozan, M. (2022). Natural sunscreen formulation with a high sun protection factor (SPF) from tengkawang butter and lignin. Industrial Crops and Products, 177(1), 114466. https://doi.org/10.1016/j.indcrop.2021.114466

De Silva, D., Ratnasooriya, W., Bandara, L., Samanmali, B., Pathirana, R., \& Abeysekara, W. (2019). Investigation of sun screening and antioxidant activity of M. indica ver "Willard." Journal of Pharmacognosy and Phytochemistry, 8(4), 1130-1133.

Farhamzah, Kusumawati, A. H., Alkandahri, M. Y., Hidayah, H., Sujana, D., Gunarti, N. S., Yuniarsih, N., Apriana, S. D., \& Agustina, L. S. (2022). Sun Protection Factor Activity of Black Glutinous Rice Emulgel Extract ( Oryza sativa var glutinosa ). Indian Journal of Pharmaceutical Education and Research, 56(1), 302-310. https://doi.org/10.5530/ijper.56.1.36

Faridah, N. (2018). Mengenal Lebih Dekat dengan Cahaya dan Warna. In Mengenal Lebih Dekat dengan Cahaya dan Warna (1st ed.). LeutikaPrio.

Himawan, H. C., Masaenah, E., \& Putri, V. C. E. (2018). AKTIVITAS ANTIOKSIDAN DAN SPF SEDIAAN KRIM TABIR SURYA DARI EKSTRAK ETANOL 70\% KULIT BUAH PISANG AMBON (Musa acuminata Colla). 3(2), 73-81.

Isfardiyana, S. H., \& Safitri, S. R. (2014). Pentingnya melindungi kulit dari sinar ultraviolet dan cara melindungi kulit dengan sunblock buatan sendiri. Jurnal Inovasi Dan Kewirausahaan, 3(2), 126-133. https://journal.uii.ac.id/ajie/article/view/7819 
Lestari, I., \& Prajuwita, M. (2021). Penentuan Nilai SPF Kombinasi Ekstrak Daun Ketepeng Dan Binahong Secara In vitro. Parapemikir: Jurnal Ilmiah Farmasi, 10(1), 1-10. https://doi.org/10.30591/pjif.v

Lisnawati, N., N.U, M. F., \& Nurlitasari, D. (2019). Penentuan Nilai Spf Ekstrak Etil Asetat Daun Mangga Gedong Menggunakan Spektrofotometri Uv - Vis. Jurnal Riset Kefarmasian Indonesia, 1(2), 157-165. https://doi.org/10.33759/jrki.v1i2.35

Lumempouw, L. I., Suryanto, E., \& Paendong, J. J. E. (2012). Aktivitas Anti UV-B Ekstrak Fenolik dari Tongkol Jagung ( Zea mays L .). JURNAL MIPA UNSRAT ONLINE, 1(1), 1-4.

Mansuri, R., Diwan, A., Kumar, H., Dangwal, K., \& Yadav, D. (2021). Potential of Natural Compounds as Sunscreen Agents. Pharmacognosy Reviews, 15(29), 47-56. https://doi.org/10.5530/phrev.2021.15.5

Narla, S., Kohli, I., Hamzavi, I. H., \& Lim, H. W. (2020). Visible light in photodermatology. Photochemical and Photobiological Sciences, 19(1), 99-104. https://doi.org/10.1039/c9pp00425d

Ollengo, M. A., \& Nthiga, E. W. (2021). Isolation, Characterization and Quantitation of Photoactive phases of Titanium (IV) oxide in skin-lightening products. Asian Journal of Research in Chemistry, 14(5), 324-330. https://doi.org/10.52711/0974-4150.2021.00055

Perumal, A., AlSalhi, M. S., Kanakarajan, S., Devanesan, S., Selvaraj, R., \& Tamizhazhagan, V. (2021). Phytochemical evaluation and anticancer activity of rambutan (Nephelium lappaceum) fruit endocarp extracts against human hepatocellular carcinoma (HepG-2) cells. Saudi Journal of Biological Sciences, 28(3), 1816-1825. https://doi.org/10.1016/j.sjbs.2020.12.027

Piccinino, D., Capecchi, E., Delfino, I., Crucianelli, M., Conte, N., Avitabile, D., \& Saladino, R. (2021). Green and scalable preparation of colloidal suspension of lignin nanoparticles and its application in eco-friendly sunscreen formulations. ACS Omega, 6(33), 21444-21456. https://doi.org/10.1021/acsomega.1c02268

Pramiastuti, O. (2019). Penentuan Nilai Spf ( Sun Protection Factor) Ekstrak Dan Fraksi Daun Kecombrang (Etlingera Elatior) Secara in vitro Menggunakan Metode Spektrofotometri. Parapemikir : Jurnal Ilmiah Farmasi, 8(1), 14-18. https://doi.org/10.30591/pjif.v8i1.1281

Puspita, W., \& Puspasari, H. (2021). PENENTUAN KADAR FLAVONOID TOTAL DAN NILAI SPF EKSTRAK ETANOL DAUN BUAS-BUAS (Premna serratifolia L.) ASAL KABUPATEN MELAWI PROVINSI KALIMANTAN BARAT. Jurnal Ilmu Farmasi Dan Farmasi Klinik, 18(01), 24-30. https://doi.org/10.31942/jiffk.v18i01.4896 
Putri, Y. D., Tristiyanti, D., \& Nurdiana, A. (2019). Uji Aktivitas Antioksidan dan Penentuan Nilai SPF Secara In vitro Ekstrak Kulit Buah Rambutan ( Nephelium lappaceum ), Manggis ( Garcinia mangostana ) Dan Durian ( Durio zibethinus ). Borneo Journal of Phamascientech, 03(02), 169-177. http://jurnalstikesborneolestari.ac.id/index.php/borneo/article/view/254/175

Rakhmatullah, A. N., Sugihartini, N., \& Susanti, H. (2020). AKTIVITAS ANTIOKSIDAN DAN NILAI SPF (Sun Protection Factor) EKSTRAK ETANOL BUAH PEPAYA (Carica papaya L.) YANG DIPEROLEH DARI SIMPLISIA DAN BUAH SEGAR. JURNAL SURYA MEDIKA, 5(2), 146-152.

Rosyidah, A. A. (2021). SKRIPSI: UJI AKTIVITAS ANTIOKSIDAN EKSTRAK AIR, EKSTRAK ETANOL DAN EKSTRAK METANOL DAUN KEDONDONG (Spondias dulcis) DENGAN MENGGUNAKAN METODE DPPH.

Rusita, Y. D., \& A.S, I. (2017). Kementerian Kesehatan Politeknik Kesehatan Surakarta Jurusan Jamu. Jurnal Kebidanan Dan Kesehatan Tradisional, 2(1), 38-43.

Sagala, Z., \& Juniasti, A. (2021). UJI PENETAPAN KADAR TOTAL FENOLIK DAN NILAI SPF ( SUN PROTECTION FACTOR ) EKSTRAK ETANOL DAUN KELOR ( MORINGA OLEIFERA L .). Indonesia Natural Research Pharmaceutical Journal, 6(2), 43-50.

Salsabila, S., Rahmiyani, I., \& Zustika, D. S. (2021). Nilai Sun Protection Factor (SPF) pada Sediaan Lotion Ekstrak Etanol Daun Jambu Air ( Syzygium aqueum ). Majalah Farmasetika, 6(Suppl 1), 123-132.

Sinala, S., Ibrahim, I., Salasa, A. M., \& Dewi, R. (2020). POTENSI AKTIVITAS TABIR SURYA EKSTRAK DAUN DAN KULIT BATANG DENGEN (Dillenia serrata) SECARA IN VITRO. Media Farmasi, 16(1), 109-115. https://doi.org/10.32382/mf.v16i1.1484

Utami, A. N., Hajrin, W., \& Muliasari, H. (2021). Formulasi Sediaan Lotion Ekstrak Etanol Daun Salam (Syzygium polyanthum (Wight) Walp.) dan Penentuan Nilai SPF Secara in vitro. $\begin{array}{llll}\text { Pharmaceutical Journal } & \text { Indonesia, }\end{array}$ https://doi.org/10.21776/ub.pji.2021.006.02.2

Watson, M., Holman, D. M., \& Maguire-Eisen, M. (2016). Ultraviolet radiation exposure and its impact on skin cancer risk. Seminars in Oncology Nursing, 32(3), 241-254. https://doi.org/10.1016/j.soncn.2016.05.005 
Jurnal Biogenesis Vol. 18 (1): 21-32, 2022

(C) Program Studi Pendidikan Biologi FKIP Universitas Riau e-ISSN : 2776-1924

Windarsih, G. (2022). Characterization of leaf morphology on several rambutan ( Nephelium lappaceum ) cultivars from Serang City, Banten, Indonesia. PROSIDING SEMINAR NASIONAL MASYARAKAT BIODIVERSITAS INDONESIA, 8(1), 18-23. https://doi.org/10.13057/psnmbi/m080103 